\title{
A Study on Chemical Disintegration of POP Ganesh Idols in Bhopal, Madhya Pradesh, India
}

\author{
Y. K. Saxena†, R.C. Verma and P. Jagan \\ Central Pollution Control Board, Regional Directorate, Parivesh Bhawan, Paryavaran Parisar, E-5, Arera Colony, \\ Bhopal-462016, Madhya Pradesh, India \\ †Corresponding author: Y. K. Saxena; dryksaxena5@yahoo.com
}

Nat. Env. \& Poll. Tech.

Website: www.neptjournal.com

Received: 16-06-2020

Revised: $20-08-2020$

Accepted: $21-09-2020$

\section{Key Words:}

Water pollution

Idol immersion

Eco-friendly practice

Water quality

\begin{abstract}
In India, festivals like Ganesh Chaturthi, Durga Puja form an integral part of its rich and diverse cultural heritage. The ritual of idol worshipping and immersion into water bodies signifies the cycle of creation and dissolution, acknowledging the rhythm of nature that all things come from nature and go seamlessly back to it for a cycle to begin. But, in recent times the practice of immersing Plaster of Paris (POP) made idols along with other decorative material into natural water bodies has immensely raised the severe issue of water pollution and creating an uncongenial aquatic ecosystem. In this purview, a pilot project for chemical disintegration of POP idols during Ganesh festival was run in Bhopal, Madhya Pradesh, India to study the effective application of a chemical method developed by CSIR-NCL, Pune by using ammonium bicarbonate. Water samples were collected before and after idol immersion activity from the tank. The detailed chemical analysis of the aqueous phase was carried out to study the effect on various parameters and application of residues. The analytical results reveal that the method has its practical utility as both the products of the reaction can further be used in chalk making and as fertiliser with dilution. The concentration of heavy metals was found minimal and in the limits in the treated aqueous phase. This paper also supports the sustainable management of such functions rather than the use of artificial materials.
\end{abstract}

\section{INTRODUCTION}

In India, idol worship has been in practice since ancient times. Ganesh festival is celebrated traditionally in all states of India with full enthusiasm as a social and community activity. The objective of the festival is mainly to bring people together and promote harmony. On festive occasions such as Vinayaka Chaturthi, Durga Puja, Sarswati Puja, etc., it has been a tradition to immerse idols in water bodies like rivers, lakes, ponds, estuaries, open coastal beaches, wells etc. Traditionally idols were made of natural clay decorated with natural things like flowers and natural colours (Reddy \& Kumar 2001). However, in recent times due to many short comes like increasing demands of idols, nonavailability of clay, high cost, delicacy of clay idols, beauty with artificial accessories etc. Plaster of Paris (POP) idols are in use in large numbers and have strongly abducted the markets. Plaster of Paris (POP) idols are very easy to make in moulds, comparatively cost less and have good strength and stability. But, POP idols when immersed in water, they don't dissolve in water and remains as such for a long period. This contributes excessively to water pollution in rivers, ponds, lakes and sea (Vyas et al. 2008). The idols are also found stuck in the water and block the natural flow of water bodies leading to stagnation. Decoration of POP idols with chemical paints and artificial accessories also supplements the issue by altering the physico-chemical attributes of water bodies like water hardness, acidic content, drop in oxygen level etc. Chemical paints along with varnish and polish used, contain many heavy metals like chromium, mercury, lead, cadmium etc. which harm the aquatic system and disturb the life cycle of aquatic animals (Bhattacharya et al. 2014). The polluted water bodies also raise a serious health issue when used for various purposes like drinking, bathing, in agriculture etc. Immersion of a large number of POP idols in natural water bodies not only deteriorates the quality of water but also poses adverse effects on the aquatic ecosystem and environment (Upadhyaya \& Bajpai 2010).

Taking it into concern and in pursuance to the Hon'ble Bombay High Court directions issued in its order dated 22/07/2008, CPCB evolved the Guidelines for immersion of idols and other puja materials reaching in the water bodies during the festival. In the guidelines it is suggested "Use of traditional clay for idol making rather than backed clay, Plaster of Paris etc. may be encouraged, allowed and promoted. The painting for idols should be discouraged and the use of chemical paints must be strictly prohibited". 
But, even after the release of guidelines for idol immersion, construction and trade of POP idols still have been observed in the market. The disintegration of POP idols by conventional crushing is not acceptable by people due to sentimental attachment to the ritual. Hence, there is a need to develop some scientific method to disintegrate these POP idols without posing any harm to the environment and sentiments of devotees. Keeping this at priority an eco-friendly scientific method for chemical disintegration of POP idols was first developed by CSIR- National Chemical Laboratory (NCL), Pune (Maharashtra) (Navale et al. 2018).

The objective of this study is to apply the chemical method developed by CSIR-NCL, Pune for the disintegration of POP Ganesh idols used in the Ganesh festival during the year 2019 as a pilot project in Bhopal city and verify the method by studying various parameters of water and its practical utility.

Plaster of Paris (POP) is chemically calcium sulphate hemihydrates having formula $\mathrm{CaSO}_{4} \cdot 1 / 2 \mathrm{H}_{2} \mathrm{O}$ and is prepared by heating Gypsum at about $150^{\circ} \mathrm{C}$. When mixed with water POP hardens fast and so, have several applications like the protective or decorative coating of walls and ceilings and for moulding and casting decorative elements, in building material, in hospital for plastering injured bones, in dental casts, idol preparation etc (Vekinis et al. 1993, Ram \& Sen 1959). The impact of idol immersion on aquatic bodies are given in Table 1.

In the present study, a pilot project would have been taken into the city Bhopal, Madhya Pradesh, India for chemical disintegration of POP Ganesh idols at Prempura ghat in the year 2019. Ammonium bicarbonate $\left(\mathrm{NH}_{4} \mathrm{HCO}_{3}\right)$ was used for the dissolution of POP idols at the ghat where artificial tanks were used for the process. Detailed chemical analysis of the aqueous phase was carried out to evaluate the change in physico-chemical parameters of the aqueous phase and possible applications of the residue.

\section{STUDY AREA}

Bhopal is a city in central India, and the capital of the state of Madhya Pradesh within the co-ordinates $23^{\circ} 15^{\prime} 0$ ", $\mathrm{N}, 77^{\circ} 25^{\prime} 0^{\prime \prime} \mathrm{E}$ and at an elevation of 1729 feet $(527 \mathrm{M})$. Bhopal is the city of serene beauty having several natural and artificial lakes dominating the city giving it the title of "City of Lakes". Also, rich in culture, art and public work having numerous heritage structures of its period. Bhopal is a cosmopolitan city where the majority of the population is dominated by the Hindus (occupying around 55\% of the total) and every year during Ganesh Festival around $6000 \mathrm{Kg}$ POP idols are immersed in lakes playing a crucial role in water pollution. This anthropogenic activity leads to deterioration of water quality and reduces the self-purifying ability of water bodies which adversely affects flora and fauna around it. Prempura ghat of the city Bhopal was selected for the study where POP Ganesh idols from the entire city were collected and transported by Bhopal Municipal Corporation (BMC). The Google map of the study area is shown in Fig. 1.

\section{MATERIALS AND METHODS}

To achieve the objective of the study to disintegrate POP idols of Ganesh in Bhopal in the year 2019 by a chemical method

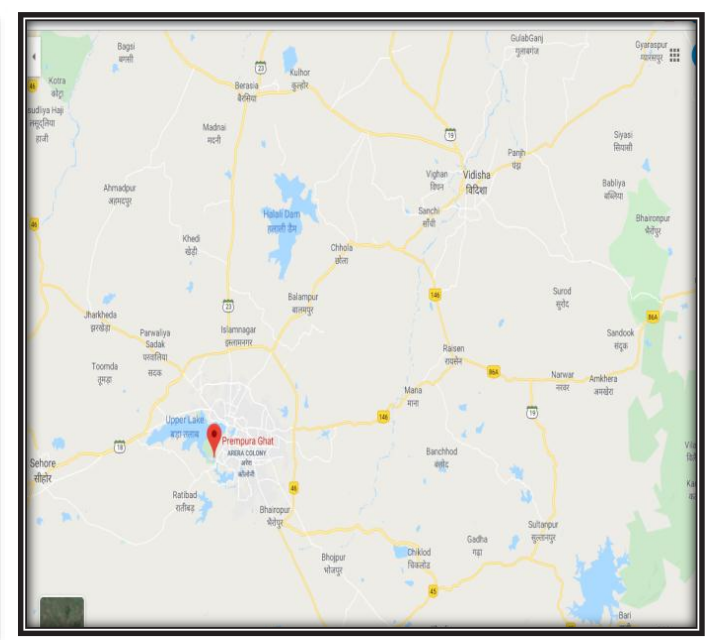

(b)

Fig 1: (a) Google map of city Bhopal, Madhya Pradesh, India (Co-ordinates $23^{\circ} 15^{\prime} 0^{\prime \prime} \mathrm{N}, 7^{\circ} 25^{\prime} 0^{\prime \prime} \mathrm{E}$ ).

(b) Prempura Ghat- Study area for the project. 
Table 1: Impact of idol immersion on aquatic life.

\begin{tabular}{|c|c|c|}
\hline S. No. & Materials contributed during immersion & Impact on the aquatic body \\
\hline 1. & Plaster of Paris & Increased dissolved solids, increased hardness, sludge, reduce life carrying capacity \\
\hline 2. & $\begin{array}{l}\text { Decoration materials viz. cloths, polish, paints, } \\
\text { ornaments, cosmetic items etc. }\end{array}$ & $\begin{array}{l}\text { Contributes suspended matters, trace metals (zinc, lead, chromium, arsenic, mercury } \\
\text { etc.), metalloids and various organic and inorganic matter, oil \& grease etc. }\end{array}$ \\
\hline 3. & Flowers, garlands, oily substances & $\begin{array}{l}\text { Increase floating suspended matter organic contamination, oil \& grease and various } \\
\text { organic and inorganic matter }\end{array}$ \\
\hline 4. & Polythene bags, plastic items & $\begin{array}{l}\text { Contribute suspended, settleable matter and hazardous material to water and chokes } \\
\text { the aquatic life }\end{array}$ \\
\hline 5. & Bamboo sticks, beauty articles & $\begin{array}{l}\text { Big pieces got collected and recycled while small pieces remain floating in the water } \\
\text { or settled at the river bottom inhabiting river flow }\end{array}$ \\
\hline 6. & Eatables, food items & Contributes oil \& grease, organics to water bodies \\
\hline
\end{tabular}

developed by CSIR-National Chemical Laboratory (NCL), Pune (Maharashtra), India all the important immersion Ghats of Bhopal city were recognised. Major immersion ghats of Bhopal city are shown in Fig. 2. The main Ghats where immersion of idols has been done in the city include Prempura ghat, Jwahar bal udhyan, Shahpura visarjan ghat, Jhoolelal visarjan ghat and Khatlapura visarjan kund etc. The experimental set up for the study was done at Prempura ghat where all the POP Ganesh idols collected from different Ghats and localities were gathered and weighed with the help of a weighing machine.

For the method, $20 \%$ w/v solution of ammonium bicarbonate (Merck India, $\mathrm{ABC}$ ) was prepared and stored in five number large-sized plastic tanks arranged at Prempura ghat each of capacity around 5000 litres. Each tank containing ammonium bicarbonate solution is fitted with a motor pump and overhead shower to ensure proper mixing and recirculation of water. This would also help to fasten the reaction by removing the topmost layer of calcium carbonate formed at the surface of idols after the disintegration of POP with ammonium bicarbonate. The ratio of POP to ammonium bicarbonate was kept 1:1. During the study, a total of around $3000 \mathrm{~kg}$ of POP idols were disintegrated by the method where each tank containing around 4000 litres of the solution having $600 \mathrm{~kg}$ of ammonium bicarbonate dissolved in it.

POP is calcium sulphate hemihydrate $\left(\mathrm{CaSO}_{4} \cdot{ }^{1} / 2 \mathrm{H}_{2} \mathrm{O}\right)$ when reacts with ammonium bicarbonate $\left(\mathrm{NH}_{4} \mathrm{HCO}_{3}\right)$ forms insoluble calcium carbonate sludge that settles at the bottom and soluble ammonium sulphate which is a well-known fertilizer (US2640757 A). The settled calcium carbonate has also found many applications like in chalk making industries, cement industries and others. It took around three days (72 hours) time for complete disintegration of POP idols inside the tanks. Continuous monitoring was done at the time of the entire process. It was found during the reaction the layers of paints over the idols were removed like peel off separately.
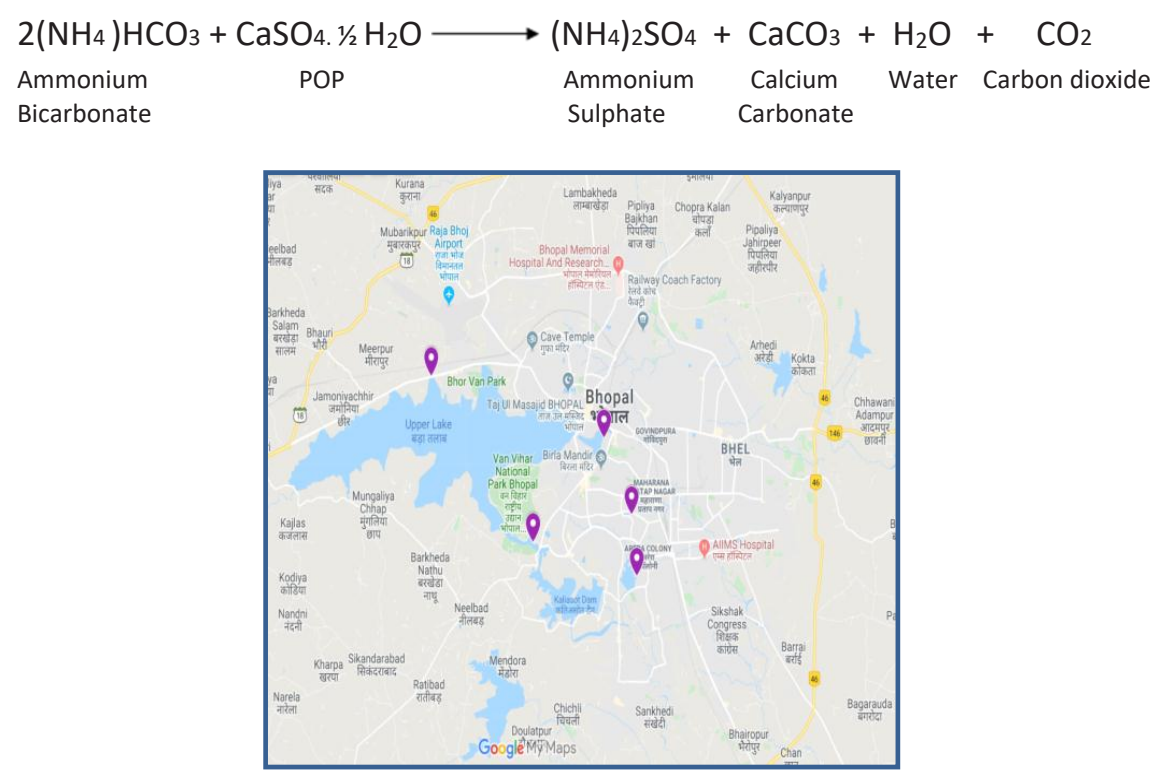

Fig 2: Major immersion ghats in Bhopal city. 
To study various chemical parameters and alteration in these characteristics after chemical reaction initial sample of freshwater was taken from the tank. Then after the completion of reaction when all the POP idols have disintegrated the sludge of calcium carbonate was allowed to settles at the bottom of tanks and sample was collected from the supernatant water. The collected samples were preserved as per the standard methods and brought in the laboratory of Central Pollution Control Board (Central), Regional Directorate, Bhopal for the analysis. To explore the utility of by-product ammonium sulphate formed after the disintegration of POP various dilutions viz. 2 times, 10 times and 20 times of supernatant water after reaction were also prepared for the analysis. The samples were coded as POP 01, POP 02, POP 03, POP 04 and POP 05.

The collected samples were analysed for important parameters including Chemical Oxygen Demand (COD), Biochemical Oxygen Demand (BOD), Total suspended Solids (TSS), Total Dissolved solids (TDS), Specific conductivity (Cond.), Total hardness (TH), Calcium hardness $(\mathrm{Ca}-\mathrm{H})$, Magnesium hardness $(\mathrm{Mg}-\mathrm{H})$, sulphate $\left(\mathrm{SO}_{4}^{-2}\right)$ and Ammonical nitrogen $\left(\mathrm{NH}_{3}-\mathrm{N}\right)$ following the standard procedures (APHA 1995).

The analysis of the majority of heavy metals including cadmium $(\mathrm{Cd})$, chromium $(\mathrm{Cr})$, copper $(\mathrm{Cu})$, lead $(\mathrm{Pb})$, nickel

Table 2: Parameters under study before and after the disintegration of POP Ganesh idols by $20 \%$ ABC solution.

\begin{tabular}{|c|c|c|c|c|c|c|}
\hline \multirow[t]{2}{*}{ S. No. } & \multirow[t]{2}{*}{ Parameters Analysed } & POP 01 & POP 02 & POP 03 & POP 04 & POP 05 \\
\hline & & Before immersion & After immersion & $\begin{array}{l}\text { After } 2 \text { times } \\
\text { Dilution }\end{array}$ & $\begin{array}{l}\text { After } 10 \text { times } \\
\text { Dilution }\end{array}$ & $\begin{array}{l}\text { After } 20 \text { times } \\
\text { Dilution }\end{array}$ \\
\hline 1 & $\mathrm{pH}$ & 6.3 & 9.7 & 9.5 & 8.7 & 7.9 \\
\hline 2 & COD (mg/L) & 4 & 115.1 & 49.79 & 11.08 & 3.24 \\
\hline 3 & $\mathrm{BOD}(\mathrm{mg} / \mathrm{L})$ & $<1$ & 7.14 & 4 & 1.58 & 1.36 \\
\hline 4 & TSS (mg/L) & 8 & 454 & 297 & 38 & 6 \\
\hline 5 & TDS (mg/L) & 600 & 56308 & 34380 & 7044 & 485 \\
\hline 6 & Sp. Cond. $(\mu \mathrm{mho} / \mathrm{cm})$ & 184 & 67500 & 42900 & 11700 & 1160 \\
\hline 7 & Ca-hardness (mg/L) & 59.13 & BDL & $\mathrm{BDL}$ & $\mathrm{BDL}$ & BDL \\
\hline 8 & Mg-hardness (mg/L) & 17.39 & BDL & BDL & $\mathrm{BDL}$ & BDL \\
\hline 9 & Total hardness (mg/L) & 76.52 & BDL & BDL & BDL & BDL \\
\hline 10 & $\mathrm{SO}_{4}^{2-}(\mathrm{mg} / \mathrm{L})$ & 9.56 & 143603 & 32305 & 7080 & 1198.97 \\
\hline 11 & $\mathrm{NH}_{3}-\mathrm{N}(\mathrm{mg} / \mathrm{L})$ & 0.439 & 0.637 & 0.546 & 0.1128 & 0.0528 \\
\hline
\end{tabular}

*BDL (Below Detection Limits)

Table 3: Heavy metal analysis of samples before and after the disintegration of POP Ganesh idols by $20 \%$ ABC solution.

\begin{tabular}{|c|c|c|c|c|c|c|}
\hline \multirow[t]{2}{*}{ S. No. } & \multirow[t]{2}{*}{ Heavy Metals } & POP 01 & POP 02 & POP 03 & POP 04 & POP 05 \\
\hline & & Before immersion & After immersion & $\begin{array}{l}\text { After } 2 \text { times } \\
\text { Dilution }\end{array}$ & $\begin{array}{l}\text { After } 10 \text { times } \\
\text { Dilution }\end{array}$ & $\begin{array}{l}\text { After } 20 \text { times } \\
\text { Dilution }\end{array}$ \\
\hline 1 & Cadmium (Cd), mg/L & BDL & 0.053 & 0.033 & BDL & BDL \\
\hline 2 & Chromium $(\mathrm{Cr}), \mathrm{mg} / \mathrm{L}$ & BDL & 0.189 & 0.056 & 0.010 & BDL \\
\hline 3 & Copper $(\mathrm{Cu}), \mathrm{mg} / \mathrm{L}$ & BDL & 0.172 & 0.085 & 0.020 & BDL \\
\hline 4 & Lead $(\mathrm{Pb}), \mathrm{mg} / \mathrm{L}$ & BDL & 0.380 & 0.215 & 0.056 & BDL \\
\hline 5 & Nickel (Ni), mg/L & BDL & 0.1018 & 0.0749 & 0.0255 & $\mathrm{BDL}$ \\
\hline 6 & $\operatorname{Iron}(\mathrm{Fe}), \mathrm{mg} / \mathrm{L}$ & 0.12 & 0.193 & 0.083 & 0.058 & BDL \\
\hline 7 & Manganese (Mn), mg/L & 0.0015 & 0.0641 & 0.0379 & 0.0078 & BDL \\
\hline 8 & Arsenic (As), $\mu \mathrm{g} / \mathrm{L}$ & BDL & 0.402 & BDL & BDL & $\mathrm{BDL}$ \\
\hline 9 & Mercury $(\mathrm{Hg}), \mu \mathrm{g} / \mathrm{L}$ & $\mathrm{BDL}$ & BDL & BDL & BDL & BDL \\
\hline
\end{tabular}

*BDL (Below Detection Limits) 
(Ni), iron (Fe), manganese (Mn), arsenic (As) and mercury $(\mathrm{Hg})$ was done using flame Atomic Absorption Spectroscope (AAS) by GBC.

\section{RESULTS AND DISCUSSION}

The environmental impact of chemical disintegration of POP Ganesh idols was assessed substantially through analysis of characteristics physicochemical parameters of the water used in the method before and after immersion. This is an excellent indicator for discussing the utility of the used water without impact on the environment. The heterogeneity and conspicuous changes in studied variables during pre immersion and post immersion phases along with the dilutions prepared are depicted in Table 2 and Fig. 3. During the study period, the $\mathrm{pH}$ of the water showed a reasonable range of variation from 6.3 to 9.7 before and after immersion respectively. The $\mathrm{pH}$ value was acidic during pre immersion and became alkaline in post immersion phase. The highest dilution of 20 times brought it at a value of 7.9. The rise in the $\mathrm{pH}$ value is because of the dissolution of ammonium bicarbonate which made it basic. Moreover, large amounts of synthetic chemicals of POP idols get mixed with water during chemical disintegration making $\mathrm{pH}$ to vary.

As the method adopted for the disintegration of POP idols was chemical, COD is an important parameter for influencing the quality of water. COD increased sharply from $4 \mathrm{mg} / \mathrm{L}$ in pre immersion phase to $115.1 \mathrm{mg} / \mathrm{L}$ after disintegration. This reduced to $3.24 \mathrm{mg} / \mathrm{L}$ on 20 times dilution in POP 05 sample which can be used in plantation. Due to substantial increase of organic load contributed by some of the straw, flowers and other materials used in idol making and decoration respectively, increase in BOD concentration was observed from $<1 \mathrm{mg} / \mathrm{L}$ to $7.14 \mathrm{mg} / \mathrm{L}$ in POP 02 sample collected after immersion. With 20 times diluted sample POP 05, the BOD reduced to $1.36 \mathrm{mg} / \mathrm{L}$ and is safe to be reused. The analysis results of samples for total hardness, Ca-hardness and Mg-hardness were all found Below Detection Limits (BDL) except for the pre immersion water sample. This could be because of the chemical reaction of ammonium bicarbonate with POP all dissolved $\mathrm{CaSO}_{4}$ and $\mathrm{MgSO}_{4}$ salts responsible for hardness in water in water also get precipitated out as $\mathrm{CaCO}_{3}$ sludge and settled at the bottom.

For the parameters TDS, specific conductivity and sulphate an extreme sharp upswing in value was observed post chemical disintegration of POP idols. The TDS which was determined as $600 \mathrm{mg} / \mathrm{L}$ in sample POP 01 pre immersion raised to $56308 \mathrm{mg} / \mathrm{L}$ in sample POP 02 collected after disintegration. An abrupt percentage increase of $9284.6 \%$ was observed which might be resulted from the increased concentration of dissolved compounds in water after the chemical disintegration of idols. A significant positive correlation with the correlation coefficient, $r=1$ was observed between TDS and specific conductivity. Specific conductivity got increment from $184 \mu \mathrm{mho} / \mathrm{cm}$ to $67500 \mu \mathrm{mho} / \mathrm{cm}$ after immersion. However, after 20 times dilution values of the same, in sample POP 05, were determined as $485 \mathrm{mg} / \mathrm{L}$ and $1160 \mu \mathrm{mho} / \mathrm{cm}$ respectively for TDS and specific conductivity which are satisfactory. The TSS calculated as $8 \mathrm{mg} / \mathrm{L}$ in pre immersion sample POP 01 was raised to $454 \mathrm{mg} / \mathrm{L}$ in the post immersion sample POP 02 due to the release of paints and other materials used for decoration of idols during the chemical process.

Ammonical nitrogen $\left(\mathrm{NH}_{3}-\mathrm{N}\right)$ concentration did not show much variation in the values. It was determined as 0.439 $\mathrm{mg} / \mathrm{L}$ in POP 01 before disintegration and $0.637 \mathrm{mg} / \mathrm{L}$ in non-diluted sample POP 02 post immersion. However, sulphate concentration exhibited rapid appreciation in the value after the chemical breakdown of POP idols by ammonium bicarbonate solution (Table 2). In the first phase before immersion, sulphate $\left(\mathrm{SO}_{4}{ }^{2-}\right)$ was $9.56 \mathrm{mg} / \mathrm{L}$ which shoot up to $143603 \mathrm{mg} / \mathrm{L}$ after reaction in non-diluted sample POP 02. The increased level of sulphate is evident from the reaction of ammonium bicarbonate with POP i.e. calcium sulphate to ammonium sulphate and calcium carbonate where carbon dioxide was released in the form of bubbles, which was confirmed by lime water test (Liu et al. 2009).

In the specific dilution, this ammonium sulphate can be used as an important nitrogen-sulphur fertilizer in fields and green belt areas for plant growth. Both the elements nitrogen and sulphur are important for the growth of plants as involved in different biological pathways and protein synthesis (Yu et al. 2018). This fertilizer is suitable for alkaline soil and where the requirement of nitrogen and sulphur is needed (Craswell et al. 1981). This is also having utility in pharmaceutical, baking, textile fire extinguishing powder and wood pulp industries. While the by-product obtained, calcium carbonate can be used as a raw material in chalk manufacturing, construction industry, metallurgy, chemical industry etc. it can also be used in the removal of environmental pollutants (Declet 2016).

Nowadays POP idols are also being decorated with a variety of materials including synthetic colours and paint which contains many hazardous chemicals and heavy metals which plays a significant role in water quality characteristics and posing serious impacts on water system as well as on human health. Considering this the water samples pre and post disintegration were analysed for heavy metals including cadmium $(\mathrm{Cd})$, chromium $(\mathrm{Cr})$, copper $(\mathrm{Cu})$, lead $(\mathrm{Pb})$, nickel (Ni), iron (Fe), manganese (Mn), arsenic (As) and mercury $(\mathrm{Hg})$. In the first phase before chemical reaction in the sample 
POP 01, except for Iron and Manganese, all other metals have concentration Below Detection Limits (BDL). However in the second phase after chemical disintegration of POP idols by ammonium bicarbonate solution in the sample POP 02 of supernatant water with no dilution the concentration of

\section{$\mathrm{pH}$ values}

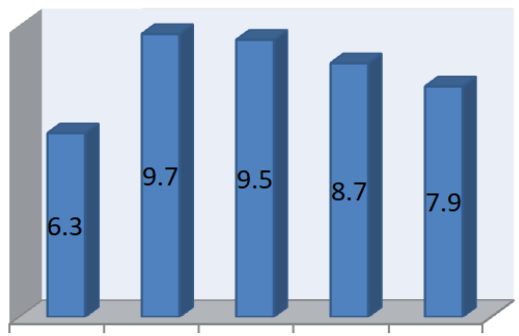

POP 01 POP 02 POP 03 POP 04 POP 05

TSS (mg/L)

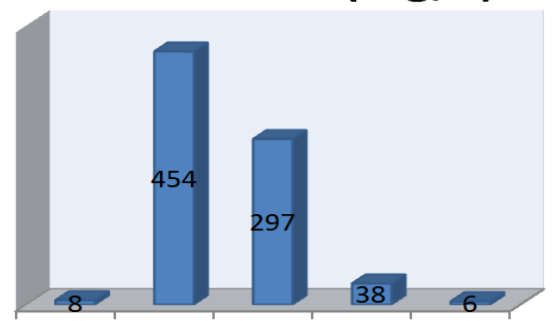

POP 01 POP 02 POP 03 POP 04 POP 05

\section{$\mathrm{BOD}(\mathrm{mg} / \mathrm{L})$}

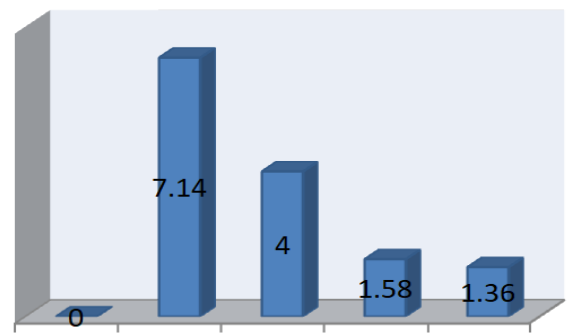

POP 01 POP 02 POP 03 POP 04 POP 05

\section{Sulphate $(\mathrm{mg} / \mathrm{L})$}

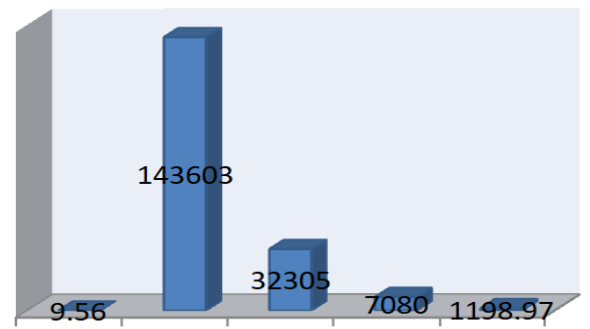

POP 01 POP 02 POP 03 POP 04 POP 05 most of the heavy metals were determined as Cadmium $(\mathrm{Cd})=$ $0.053 \mathrm{mg} / \mathrm{L}$; Chromium $(\mathrm{Cr})=0.189 \mathrm{mg} / \mathrm{L}$; Copper $(\mathrm{Cu})=$ $0.172 \mathrm{mg} / \mathrm{L} ;$ Lead $(\mathrm{Pb})=0.380 \mathrm{mg} / \mathrm{L} ; \operatorname{Nickel}(\mathrm{Ni})=0.1018$ $\mathrm{mg} / \mathrm{L}$; Iron $(\mathrm{Fe})=0.193 \mathrm{mg} / \mathrm{L} ;$ Manganese $(\mathrm{Mn})=0.0641$ $\mathrm{mg} / \mathrm{L} ;$ Arsenic $(\mathrm{As})=0.402 \mu \mathrm{g} / \mathrm{L}$ and Mercury $(\mathrm{Hg})=\mathrm{BDL}$.
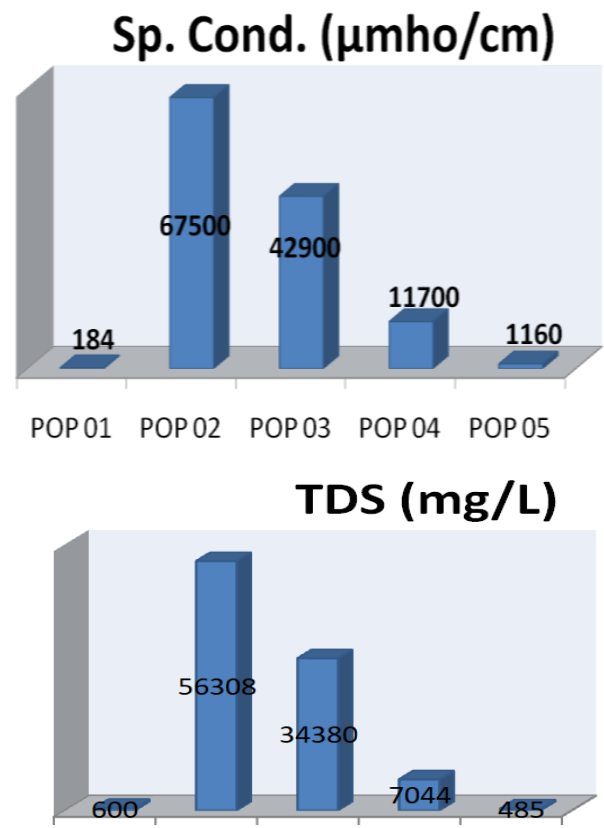

POP 01 POP 02 POP 03 POP 04 POP 05

$\operatorname{COD}(\mathrm{mg} / \mathrm{L})$

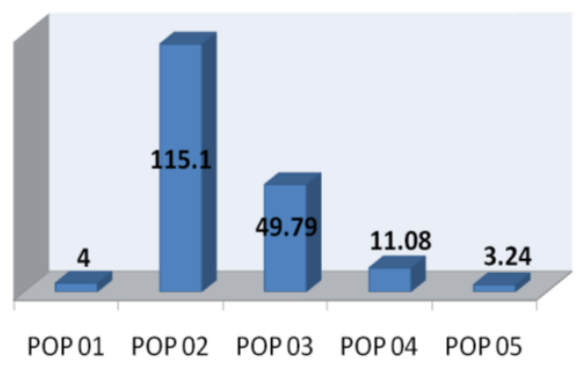

$\mathrm{NH}_{3}-\mathbf{N}(\mathrm{mg} / \mathrm{L})$

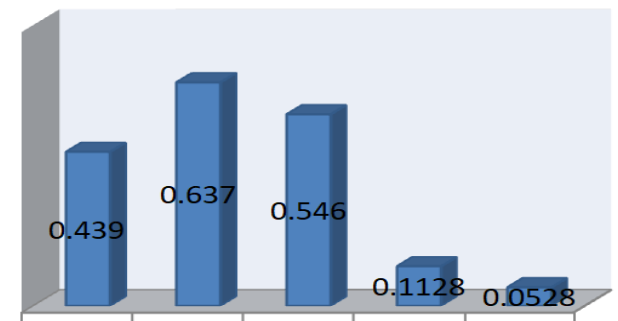

POP 01 POP 02 POP 03 POP 04 POP 05

Fig. 3: Changes in studied variables during pre immersion and post immersion phases along with the dilutions prepared. 
The results of Heavy Metal analysis of samples before and after disintegration of POP Ganesh idols are depicted in Table 3. The results expressed difficulty in the utility of this water because of heavy metal contents in it. But, after 20 times dilution in sample POP 05, their concentration reduces to satisfactory limits.

\section{CONCLUSION}

Plaster of Paris (POP) idol immersion in natural water bodies has immense contribution to water pollution which raised the concern for a safe and eco-friendly way to deal it. Complete chemical disintegration of POP idols by ammonium bicarbonate solution gives value-added products having reasonable practical utilities with no hostile effects. The post disintegration chemical water after specific dilutions can be effectively used as a fertilizer in agriculture. However, the method is not found so cost-effective as $99.99 \%$ purity ammonium bicarbonate is mandatory which costs high and the process requires a specific set up with tanks, mesh, overhead showers, continuous mixing, proper PPEs, supervision etc. but, in the transition stage from POP to complete clay idols, this chemical method seems to be a better and environmentally safe alternative with feasibility to arrest water pollution. But a complete ban on the use of POP idols is always preferable and should be adopted in such festivals.

\section{ACKNOWLEDGEMENT}

Authors are thankful to Dr Shubhangi B. Umbarkar, CSIRNCL, Pune (MS) for sharing her best knowledge. We extend gratitude to Shri Tarun Kumar Pithode, Collector, Bhopal and Municipal Corporation, Bhopal for providing constant support, facilities and financial assist to make this pilot project successful. We also acknowledge the Central
Pollution Control Board, Regional Directorate, Bhopal for all the contributions.

\section{REFERENCES}

APHA 1995. Standard Methods For The Examination of Water and Wastewater. $19^{\text {th }}$ edition, American Public Health Association, Washington D.C.

Bhattacharya, S., Bera, A., Dutta, A. and Ghosh, U.C. 2014. Effects of idol immersion on the water quality parameters of Indian water bodies: environmental health perspectives. International Letters of Chemistry, Physics and Astronomy, 20.

Craswell, E.T., Datta, S.K., Obcemea, W.N. and Hartantyo, M. 1981. Time and mode of nitrogen fertilizer application to tropical wetland rice. Fertil. Res., 2: 247-259. https://doi.org/10.1007/BF01050197.

Declet, A. 2016. Calcium carbonate precipitation: a review of the carbonate crystallization process and application in bio-inspired composites. Rev. Adv. Mater. Sci., 44:87-107.

Liu, F., Wang, S. and Zhang, X. 2009. Study on ammonium bicarbonate decomposition after $\mathrm{CO}_{2}$ sequestration by ammonia method. Huanjing Kexue Xuebao/Acta Sci. Circumst., 29: 1886-1890.

Navale, G.R., Gohil, K.N., Puppala, K.R., Shinde, S.S., Umbarkar, S. and Dharne, M.S. 2018. Rapid and greener method for utilization of POP waste generated from biomedical samples. Int. J. Environ. Sci. \& Tech. https://doi.org/10.1007/s13762-018-2070-7.

Ram, A. and Sen, S. 1959. Plaster of Paris. Trans Indian Ceram Sic., 18: 35-54. https://doi.org/10.1080/037150X.1959.11011909.

Reddy, V.M. and Kumar, V.A. 2001. Effects of Ganesh idol immersion on some water quality parameters of Hussain Sagar. Curr. Sci., 81: 1412.

Upadhyaya, A. and Bajpai, A. 2010. Comparison of physico-chemical parameters of various water bodies in and around Bhopal (M.P.). Asian J. Chem. Environ. Res., 3: 20-26.

Vekinis, G., Ashby, M.F. and Beaumont, P.W.R. 1993. Plaster of Paris as a model material for brittle porous solids. J. Mater. Sci., 28: 3221-3227. https:// doi.org/10.1007/BF00354239.

Vyas, A., Bajpai, A., Verma, N. and Dixit S. 2008. Heavy metal contamination cause of idol immersion activities in urban lake Bhopal, India. J. Appl. Sci. Ad Environ. Mang., 11(4): 37-39.

Yu, Z., Juhasz, A. and Islam, S. 2018. Impact of mid-season sulphur deficiency wheat nitrogen metabolism and biosynthesis of grain protein. Sci. Rep., 8: 2499. https://doi.org/10.1038/s41598-01820935-8. 